\title{
Pengembangan Media Pembelajaran Berbasis Augmented Reality Book Simulasi Perkembangbiakan Hewan Pada Mata Pelajaran IPA Studi Kasus Kelas VI- SD Negeri 4 Suwug
}

\author{
I Gede Arya Sudarmayana, Made Windu Antara Kesiman², Nyoman Sugihartini ${ }^{3}$ \\ Program Studi Pendidikan Teknik Informatika ${ }^{1,2,3}$ \\ Universitas Pendidikan Ganesha \\ Singaraja, Indonesia \\ aryasudarmayana@gmail.com ${ }^{\mathbf{1}}$, antara.kesiman@undiksha.ac.id ${ }^{2}$, sugihartini@undiksha.ac.id $^{3}$
}

\begin{abstract}
Abstrak- The purpose of this research is to develop learning media based on the Augmented Reality Book of Animal Breeding on the Android platform, as one of the media to facilitate and provide it's an attraction in understanding animal breeding material in Natural Sciences (IPA) lessons in SDN 4 SUWUG. The development of the Augmented Reality Book Animal Breeding application uses the ADDIE model which consists of five stages, namely the Analyze, Design, Development, Implementation, and Evaluation stages. In this model, an Evaluation process is carried out in each of the stages that are passed continuously to produce products that meet the needs in the field. The final result of this development is in the form of Augmented Reality Animal Breeding applications that can be used via mobile devices with the Android operating system. The final results of this study indicate that the application of Augmented Reality Animal Breeding is included in the criteria very well. The results obtained based on the black-box test obtained a percentage of success of $100 \%$, white-box test obtained a percentage of success of $100 \%$, content expert test, and media expert test were processed with Gregory Technique with an average of 1.00 calculation results if converted into a table of achievement levels expert validity criteria included Very High, and for the user response test with a percentage of $93.4 \%$ so that it falls into the rating criteria that is Very Good.
\end{abstract}

Keywords: augmented reality book, learning media, animal breeding, ADDIE model, android.

\section{PENDAHULUAN}

Pembelajaran merupakan suatu proses yang melibatkan interaksi antara siswa, guru, dan sumber belajar. Menurut Peraturan
Pemerintah No.19, Bab IV pasal 19 ayat 1 "proses pembelajaran pada satuan pendidikan diselenggarakan secara interaktif, inspiratif, menyenangkan, menantang, memotivasi peserta didik untuk berpartisipasi aktif, serta memberikan ruang yang cukup bagi prakarsa, kreativitas, dan kemandirian sesuai dengan bakat, minat, dan perkembangan fisik serta psikologi siswa. Oleh sebab itu sebagai seorang tenaga pendidik harus bisa merancang pembelajaran yang menarik sehingga bisa mewujudkan cita-cita pemerintah tersebut.

SD Negeri 4 Suwug merupakan sekolah dasar yang ada di Kabupaten Buleleng. Dalam sistem pendidikannya, kegiatan pembelajaran di kelas terbagi menjadi 2 metode yakni pemberian materi (ceramah) dan praktik. Prinsip pengajaran yang baik adalah jika proses belajar mampu mengembangkan konsep generalisasi dan menjadikan bahan abstrak ke hal yang jelas dan nyata. Selain itu agar mendapatkan hasil pembelajaran yang optimal hendaknya siswa harus terlibat aktif dalam proses pembelajaran. Pembelajaran siswa aktif dapat diwujudkan dengan menggunakan media pembelajaran yang tepat. Interaksi yang terjadi selama proses belajar dipengaruhi oleh lingkungan belajarnya, diantaranya adalah efektifitas media pembelajarannya [1]. Penggunaan media pembelajaran yang tepat akan dapat mengatasi sikap pasif dari anak didik. Pemilihan metode mengajar tertentu akan mempengaruhi jenis media pengajaran yang sesuai, meskipun masih ada berbagai aspek lain yang harus diperhatikan dalam memilih media, antara lain tujuan pengajaran, jenis tugas dan respons yang diharapkan dapat dikuasai siswa 


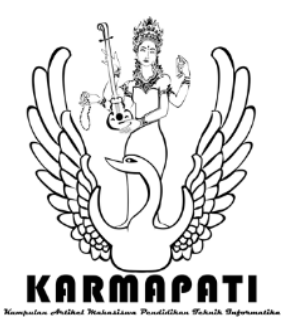

setelah pengajaran. Meskipun demikian, dapat dikatakan bahwa salah satu fungsi utama media pengajaran adalah sebagai alat bantu mengajar yang turut mempengaruhi kondisi dan lingkungan yang diciptakan oleh guru [2]. Oleh sebab itu penggunaan media pembelajaran yang tepat akan berdampak pada pemahaman siswa tentang materi yang disampaikan akan lebih optimal, terutama untuk materi yang dianggap sulit untuk siswa. Berdasarkan hal tersebut peneliti melakukan penyebaran angket tentang mata pelajaran yang dianggap sulit oleh siswa dan dapat disimpulkan 64.7\% siswa mengalami kesulitan di mata pelajaran IPA, kemudian peneliti melakukan analisis daftar nilai dan didapat hasil 55,6\% siswa mendapatkan nilai di bawah KKM (Kriteria Ketuntasan Minimal) pada materi perkembangbiakan hewan. Selanjutnya, temuan saat melakukan wawancara dengan guru mata pelajaran yaitu guru hanya menggunakan metode ceramah dalam menyampaikan materi, terbatasnya sumber belajar berupa buku pegangan siswa dalam pembelajaran materi perkembangbiakan hewan, dan belum adanya media pembelajaran yang seharusnya dapat menjadikan suasana belajar lebih interaktif dan menyenangkan.

Untuk mengatasi masalah tersebut, diperlukan adanya suatu media yang dapat memberikan pemahaman secara mudah dan menarik mengenai materi pembelajaran perkembangbiakan hewan. Seiring dengan perkembangan teknologi, pemanfaatannya disegala bidang sudah merupakan sebuah keharusan. Salah satu pemanfaatan teknologi adalah adanya aplikasi Augmented Reality $(A R)$. Hal yang perlu ditekankan adalah keberadaan aplikasi augmented reality bukan untuk menggantikan tugas-tugas guru, tetapi untuk menjadi media pembelajaran yang dapat memotivasi dan mempermudah siswa dalam memahami isi materi pembelajaran. Sebuah penelitian sebelumnya yang dilakukan Ahmad Burhanudin dengan judul "Pengembangan Media Pembelajaran Augmented Reality pada Mata Pelajaran Dasar Elektronika di SMK Hamong Putera 2 Pakem". Hasil dari penelitian ini dinyatakan media pembelajaran augmented reality pada mata pelajaran dasar elektronika berfungsi dengan baik dan layak digunakan sebagai media pembelajaran [3].

Berdasarkan permasalahan yang terjadi dan beberapa solusi yang pernah ditawarkan peneliti sebelumnya mengenai aplikasi Augmented Reality (AR) yang terbukti sudah berdampak positif diberbagai bidang, maka pada penelitian ini peneliti mencoba untuk mengintegrasikan $A R$ ke dalam pembelajaran materi perkembangbiakan hewan, peneliti bermaksud untuk melakukan penelitian dengan judul "Pengembangan Media
e-ISSN: 2685-7006 |p-ISSN: 2252-9063

Kumpulan Artikel Mahasiswa Pendidikan Teknik Informatika

(KARMAPATI)

Volume 10, Nomor 1,Tahun 2021
Pembelajaran Berbasis Augmented Reality Book Perkembangbiakan Hewan pada Mata pelajaran IPA Studi Kasus Kelas VI- SD Negeri 4 Suwug"

\section{KAJIAN TEORI}

\section{A. Mata Pelajaran IPA Materi Perkembangbiakan Hewan}

IPA adalah usaha manusia dalam memahami alam semesta melalui pengamatan yang tepat pada sasaran, serta menggunakan prosedur, dan dijelaskan dengan penalaran sehingga mendapatkan suatu kesimpulan [4]. Perkembangbiakan hewan adalah cara hewan untuk melestarikan jenisnya atau keturunannya agar tidak punah. Hewan berkembangbiak dengan cara yang berbeda-beda. Secara umum, ada dua macam perkembangbiakan hewan. Hewan berkembangbiak dengan cara kawin dan tak kawin. Perkembangbiakan secara kawin disebut dengan perkembangbiakan generatif dan perkembangbiakan secara tak kawin disebut dengan perkembangbiakan vegetative [5].

\section{B. Media Pembelajaran}

Menurut Lisiswanti, media pembelajaran adalah mediamedia yang digunakan dalam pembelajaran, yaitu meliputi alat bantu guru dalam mengajar serta sarana pembawa pesan dari sumber belajar ke penerima pesan belajar (siswa) [6]. Tujuan dari media pembelajaran berbasis augmented reality perkembangbiakan hewan yang dikembangkan oleh peneliti tentunya sesuai dengan tujuan dari "media itu sendiri", yang bermaksud untuk menyampaikan informasi kepada para penerima/ pemakai media, melalui animasi 3D serta narasi perkembangbiakan hewan yang diproyeksikan secara real time agar pembelajaran tersampaiakan dengan jelas kepada penerima atau pemakai media.

\section{Teknologi Augmented Reality}

Augmented reality adalah Augmented reality merupakan suatu cara untuk menggabungkan benda atau obyek maya ke dalam lingkungan nyata pengguna lalu memproyeksikannya dalam waktu nyata [7]. Terdapat 2 jenis metode pencitraan yang diterapkan dalam pembuatan augmented reality yaitu marker base tracking dan markerless augmented reality. Marker base tracking adalah metode augmented reality yang membutuhkan penanda (marker) berupa gambar 2D untuk membentuk reality, sedangkan markerless augmented reality adalah metode augmented reality tanpa menggunakan sebuah marker untuk menampilkan elemen- 


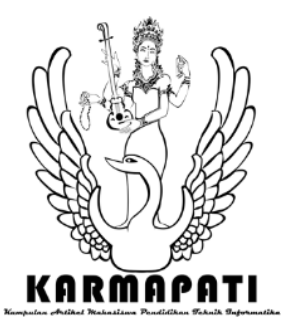

elemen digital [8]. Dalam penelitian ini peneliti menggunakan metode Marker base tracking dalam mengembangkan media pembelajaran berbasis augmented reality book perkembangbiakan hewan.

\section{Augmented Reality Book}

Augmented Reality Book (AR-Book) atau yang dalam bahasa Indonesia berarti buku berbasis augmented reality merupakan penggabungan antara buku biasa dengan teknologi $A R$. AR-Book secara garis besar memiliki dua komponen utama, yaitu buku yang dilengkapi dengan marker berjenis Quick Response Code (ORC) pada hampir setiap halamannya, dan yang kedua yaitu peralatan untuk menangkap marker dan menampilkan hasilnya. Augmented Reality Book termasuk dalam kategori sumber belajar yang didesain khusus, karena dikembangkan sebagai komponen dalam hal mempermudah penggunaan memahami isi buku dengan cara menampilkan objek berupa 3 dimensi pada gambar 2 dimensi yang tertera pada buku. Alat tersebut dapat berbentuk handheld display (HHD), head mounted display $(H M D)$, virtual retinal display (VRD), atau bahkan tampilan berbasis layar biasa [9].

\section{E. Augmented Reality dalam Pendidikan}

Ilmu Pengetahuan Alam (IPA) merupakan salah satu disiplin ilmu di mana memiliki berbagai macam istilah ilmiah didalamnya, sehingga membutuhkan penalaran khusus untuk memahami bahasa-bahasa abstrak yang terdapat dalam ilmu tersebut. Teknologi $A R$ membantu siswa untuk lebih memahami objek-objek dalam pembelajaran IPA secara lebih nyata dengan waktu yang fleksibel dan pengalaman yang mengesankan, sehingga minat belajar menjadi meningkat.

\section{F. Vuforia $(S D K)$}

Vuforia adalah Augmented Reality Software Development Kit $(S D K)$ untuk perangkat bergerak yang memungkinkan pembuatan aplikasi Augmented reality. Vuforia adalah library pembangun aplikasi Augmented reality yang dikembangkan oleh vendor semi konduktor Qualcomm asal California, Amerika Serikat. Vuforia menggunakan teknologi Computer Vision untuk mengenali dan melacak marker atau image target yang sederhana, seperti kotak secara real- time [10].

\section{G. Unity $3 D$}

e-ISSN: 2685-7006 | p-ISSN: 2252-9063

Kumpulan Artikel Mahasiswa Pendidikan Teknik Informatika

(KARMAPATI)

Volume 10, Nomor 1,Tahun 2021
Unity $3 D$ adalah game engine merupakan sebuah software pengolah gambar, grafik, suara, input, dan lain-lain yang ditujukan untuk membuat suatu game, meskipun tidak selamanya harus untuk game. Kelebihan dari game engine ini adalah bisa membuat game berbasis 3D maupun 2D dan sangat mudah digunakan [11].

\section{H. Blender}

Blender adalah software pengembangan model 3D yang bersifat gratis (open source). Software ini mendukung seluruh proses pengembangan 3D, mulai dari modeling, rigging, animation, simulation, rendering, compositing, dan juga motion tracking, bahkan editing video dan juga pengembangan game [12].

\section{Sistem Operasi Android}

Android adalah sebuah sistem operasi untuk perangkat mobile berbasis linux yang mencangkup sistem operasi, middleware dan aplikasi Android menyediakan platform terbuka bagi para pengembang untuk menciptakan aplikasi mereka. Sejak resmi diluncurkan sebagai sistem operasi open source, Android telah mengalami beberapa kali pembaharuan [13].

\section{METODOLOGI PENELITIAN}

Pengembangan Media Pembelajaran Berbasis Augmented Reality Book Perkembangbiakan Hewan pada mata pelajaran IPA Studi Kasus Kelas VI- SD Negeri 4 Suwug menggunakan metode penelitian dan pengembangan (Research and Development). $R \& D$ adalah sebuah proses yang digunakan untuk mengembangkan produk pendidikan yang bisa dipertanggungjawabkan. Penelitian ini dilakukan untuk mengembangkan dan menguji kelayakan media pembelajaran berbasis augmented reality untuk mata pelajaran Ilmu Pengetahuan Alam (IPA) materi Perkembangbiakan Hewan kelas VI di SD Negeri 4 Suwug.

Penelitian ini menggunakan model pengembangan ADDIE. Model pengembangan ini adalah model perencanaan pembelajaran yang efektif dan efesien serta prosesnya bersifat interaktif, di mana memberikan kesempatan untuk melakukan evaluasi dan revisi secara terus menerus dalam setiap fase yang dilalui, sehingga produk yang dihasilkan menjadi produk yang valid dan reliabel. Model pengembangan $A D D I E$ terdiri dari lima tahap pengembangan yaitu: Analisis (Analysis), Desain 


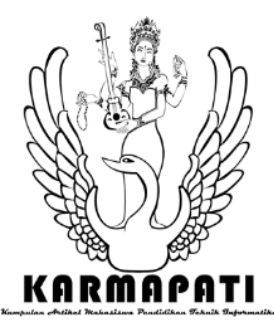

e-ISSN: 2685-7006|p-ISSN: 2252-9063

Kumpulan Artikel Mahasiswa Pendidikan Teknik Informatika

(KARMAPATI)

Volume 10, Nomor 1,Tahun 2021

(Design), Pengembangan (Development), Implementasi (Impelementation), dan Evaluasi (Evaluation).

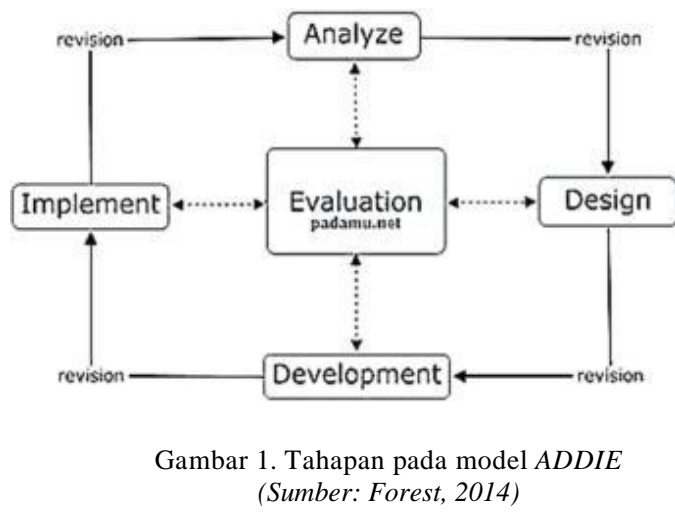

1. Analisis (Analysis)

Tahap pertama model ADDIE adalah analisis, peneliti melakukan identifikasi permasalahan yang ditemukan sehingga informasi dan kebutuhan dapat dijadikan acuan dalam mengembangkan buku digital dan aplikasi augmented reality simulasi perkembangbiakan hewan. Dalam tahap ini dijelaskan mengenai analisis masalah dan solusi, modul ajar buku digital, analisis sumber belajar, analisis kebutuhan yang berupa kebutuhan fungsional dan non fungsional, serta analisis silabus mata pelajaran.

\section{Desain (Design)}

Tahap desain yaitu proses mempelajari masalah dan kemudian mendesain alternatif solusi yang akan ditempuh untuk mengatasi masalah yang sudah diidentifikasi. Pada tahap ini, peneliti melakukan beberapa proses perancangan yaitu perancangan model fungsional perangkat lunak, menentukan batasan perancangan perangkat lunak, perancangan antarmuka aplikasi, perancangan buku $A R$, perancangan arsitektur perangkat lunak, dan perancangan struktur menu perangkat lunak.

\section{Pengembangan (Development)}

Pada tahap ini dilakukan kegiatan produksi media pembelajaran berbasis augmented reality perkembangbiakan hewan dan juga buku augmented reality. Pada tahap ini, aplikasi "perkembangbiakan hewan" berbasis augmented reality dan juga buku augmented reality mulai dikembangkan sesuai dengan yang sudah ditetapkan pada tahap design.

\section{Implementasi (Implementation)}

Pada tahap implementasi penulis melakukan pelatihan penggunaan media pembelajaran berbasis augmented reality untuk mata pelajaran Ilmu Pengetahuan Alam materi Perkembangbiakan Hewan kepada guru dan siswa kelas VI SD Negeri 4 Suwug.

\section{Evaluasi (Evaluation)}

Setelah dilakukannya tahap implementasi, maka pada tahap ini peneliti melakukan proses evaluasi. Evaluasi dapat didefinisikan sebagai sebuah proses yang dilakukan untuk memberikan nilai terhadap media pembelajaran. Evaluasi pada penelitian ini yaitu uji white box, uji black box, uji ahli isi, uji ahli media, dan uji respons pengguna.

\section{HASIL DAN PEMBAHASAN}

1. HASIL

1. Analisis (Analysis)

Tahap ini dijelaskan mengenai analisis masalah dan solusi, analisis modul buku digital, serta analisis perangkat lunak.

\section{a. Analisis Masalah dan Solusi}

Berdasarkan analisis masalah pada proses pembelajaran perakitan komputer, terdapat beberapa masalah yang menjadi kelemahan, antara lain: 1) Pada proses pembelajaran di kelas VI, guru menyampaikan materi perkembangbiakan hewan dengan menggunakan metode ceramah yang masih kurang efektif dilakukan. 2) Terbatasnya sumber belajar berupa buku pegangan siswa dalam pembelajaran materi perkembangbiakan hewan. 3) Belum adanya media pembelajaran yang seharusnya dapat menjadikan suasana belajar lebih interaktif dan menyenangkan.

\section{b. Analisis Modul Ajar Buku Digital}

Adapun kompetensi dasar yang terdapat di Silabus (Terlampir) akan digunakan pembuatan media pembelajaran berbasis Augmented Reality 


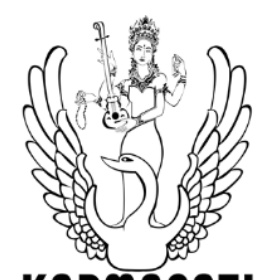

e-ISSN: 2685-7006|p-ISSN: 2252-9063

Kumpulan Artikel Mahasiswa Pendidikan Teknik Informatika

(KARMAPATI)

Volume 10, Nomor 1,Tahun 2021

\section{KARMAPATI}

1) Mengidentifikasi cara perkembangbiakan hewan.

4 indikator yang dicapai terdapat tujuan pembelajaran diantarinya:

1) Mengidentifikasi berbagai cara hewan berkembangbiak

2) Memahami dan menyebutkan hewan yang berkembangbiak dengan cara bertelur, melahirkan, bertelur- melahirkan, bertunas, dan membelah diri

3) Memahami ciri-ciri hewan yang berkembangbiak dengan cara bertelur, melahirkan, bertelur- melahirkan, bertunas, dan membelah diri

4) Memahami Siklus dari setiap jenis perkembangbiakan hewan baik itu secara bertelur, melahirkan, bertelurmelahirkan, bertunas, dan membelah diri

\section{c. Analisis Kebutuhan Perangkat Lunak}

Kebutuhan perangkat lunak dapat dikategorikan menjadi 2 bagian sebagai kebutuhan fungsional dan non-fungsional. Kebutuhan fungsional dan non-fungsional aplikasi yang akan dibangun peneliti :

Kebutuhan fungsional, mampu menampilkan antarmuka pilihan Menu Utama yaitu terdiri dari menu Panduan, Unduh Marker, AR Camera, Materi, Tentang, dan Keluar; Mampu mendeteksi marker yang ada pada Buku $A R$ Perkembangbiakan Hewan; Mampu menampilkan animasi 3 dimensi sesuai dengan marker yang dideteksi; Mampu menampilkan narasi audio pada obyek 3 dimensi yang ditampilkan; Mampu menampilkan menampilkan rotasi pada obyek 3 dimensi yang ditampilkan; Mampu menampilkan zoom in dan zoom out pada obyek 3 dimensi yang ditampilkan; Mampu menampilkan animasi perkembangbiakan hewan; Mampu menampilkan informasi tentang petunjuk penggunaan aplikasi dalam bentuk teks; Mampu mengunduh marker atau Buku AR Perkembangbiakan Hewan; Mampu menampilkan informasi profil pengembang aplikasi.

Kebutuhan non-fungsional, aplikasi yang dibangun harus memiliki materi yang sesuai dengan silabus materi pelajaran, aplikasi yang akan dibangun dapat menampilkan visualisasi simulasi objek 3D dengan teknik augmented reality, aplikasi yang dibangun harus interaktif dan edukatif agar memudahkan pengguna dalam memahami materi aplikasi yang dibangun harus mudah dioperasikan oleh pengguna (user friendly).

d. Masukan dan Keluaran Perangkat Lunak

Masukan dari aplikasi augmented reality perkembangbiakan hewan adalah berupa marker/penanda dalam bentuk gambar 2D. marker/penanda tersebut akan ditempatkan di dalam Buku Augmented Reality Perkembangbiakan Hewan

Keluaran dari aplikasi Augmented Reality Simulasi Perkembangbiakan Hewan adalah animasi 3D perkembangbiakan hewan dan audio narasi perkembangbiakan hewan.

2. Desain

a. Perancangan Model Fungsional

1) Use Case Diagram

Use Case Diagram merupakan diagram yang menggambarkan actor (pengguna sistem lain), use case (deskripsi fungsi dari sebuah sistem) dan relasinya (Laman, 2005). Use Case Diagram Aplikasi Media pembelajaran Berbasis Augmented Reality Book Simulasi Perkembangbiakan Hewan sebagai berikut:

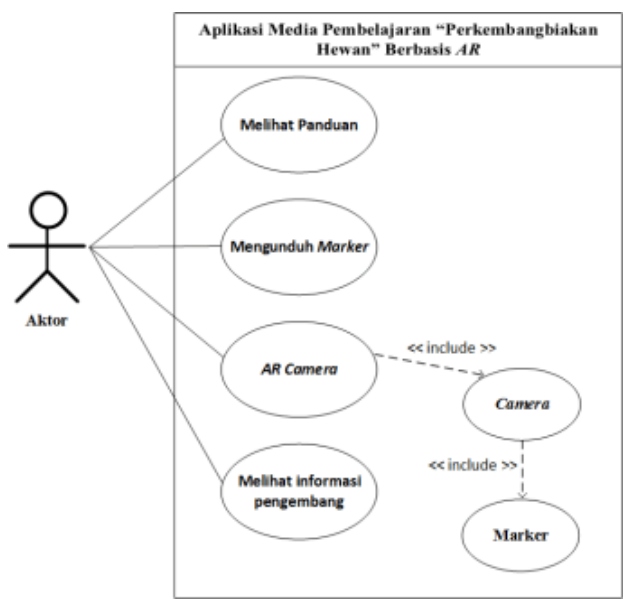

Gambar 2. Use Case Diagram 
e-ISSN: 2685-7006 | p-ISSN: 2252-9063

Kumpulan Artikel Mahasiswa Pendidikan Teknik Informatika

(KARMAPATI)

Volume 10, Nomor 1,Tahun 2021

\section{KARMAPATI}

\section{2) Activity Diagram}

a) Activity Diagram Menampilkan Panduan Aplikasi

Saat User membuka aplikasi augmented reality book simulasi perkembangbiakan hewan, maka aplikasi akan menampilkan menu utama. Terdapat 4 jenis menu pada menu utama yaitu menu Panduan, menu Unduh Marker, menu $A R$ Camera, dan menu Tentang. Saat user memilih menu Panduan, maka aplikasi akan menampilkan informasi cara penggunaan aplikasi augmented reality book simulasi perkembangbiakan hewan.

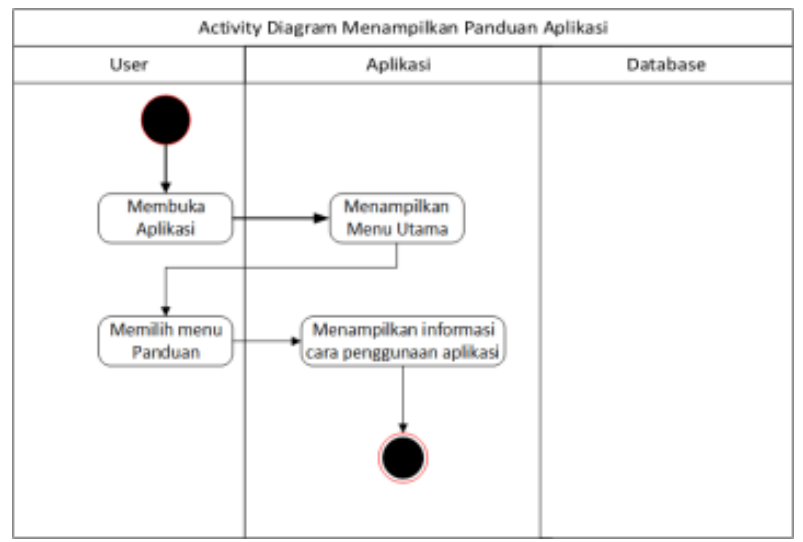

Gambar 3. Activity Diagram Menampilkan Panduan Aplikasi

b) Activity Diagram Mengunduh Marker

Saat User memilih menu Unduh Marker maka, aplikasi akan menampilkan halaman unduh Buku $A R$.

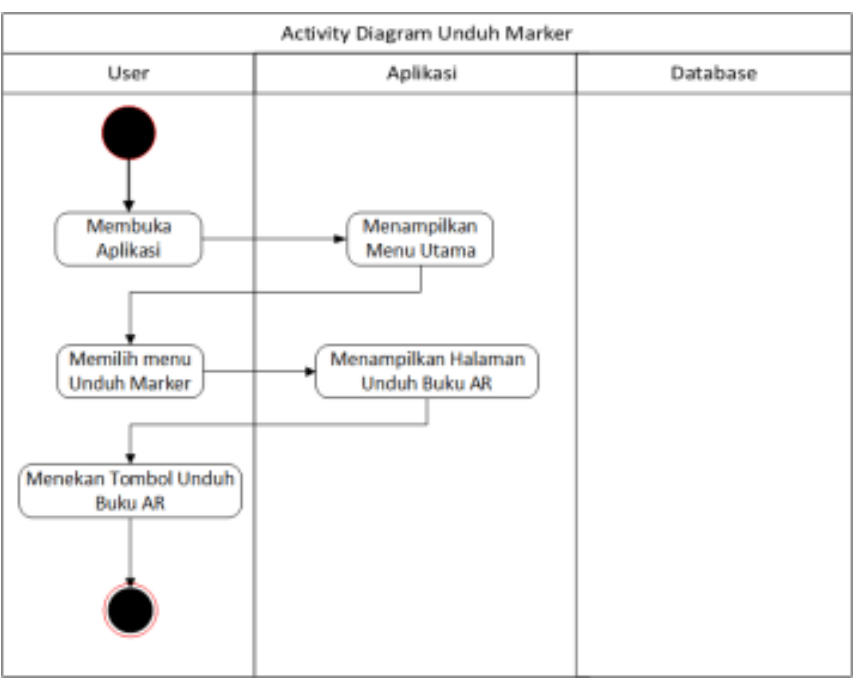

Gambar 4. Activity Diagram Mengunduh Marker

c) Activity Diagram Menampilkan Obyek 3D

Saat User memilih menu AR Camera maka aplikasi akan secara otomatis mengaktifkan Camera Smart phone. Selanjutnya User dapat mengarahkan Camera Smart phone ke Penanda/ Marker yang terdapat pada Buku AR maka aplikasi akan otomatis melakukan proses Scan Marker. Ketika Marker berhasil terbaca maka aplikasi akan secara otomatis menampilkan obyek 3D. User dapat menggunakan fitur Mute, rotasi obyek 3D, Zoom- In obyek 3D dan Zoom- Out obyek 3D. 
e-ISSN: 2685-7006|p-ISSN: 2252-9063

Kumpulan Artikel Mahasiswa Pendidikan Teknik Informatika

(KARMAPATI)

Volume 10, Nomor 1,Tahun 2021

KARMAPATI

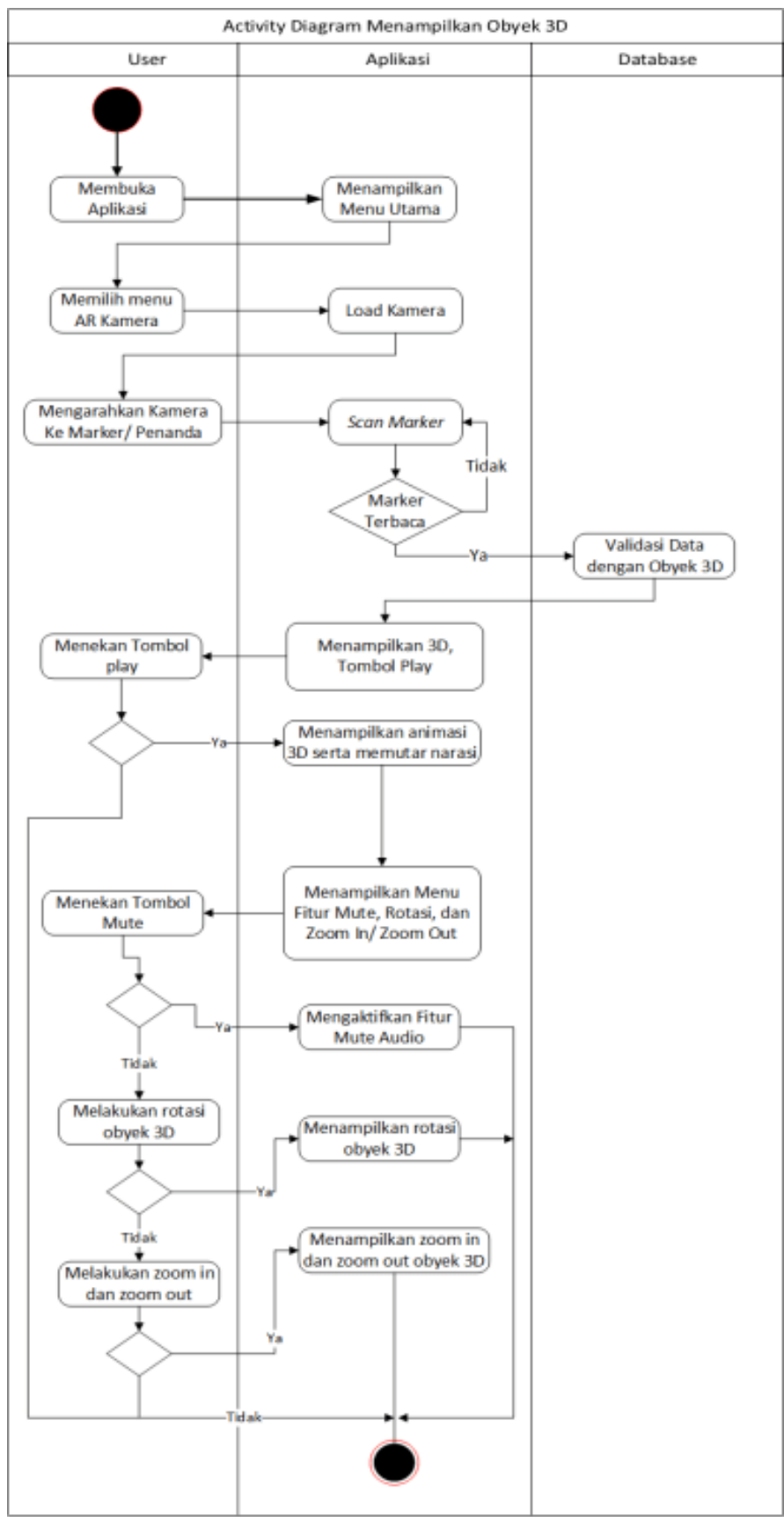

Gambar 5. Activity Diagram Menampilkan Obyek $3 D$ d) Activity Diagram Menampilkan Informasi Pengembang
Aplikasi

Saat User memilih menu Tentang, aplikasi akan menampilkan informasi dari pengembang aplikasi augmented reality book simulasi perkembangbiakan hewan

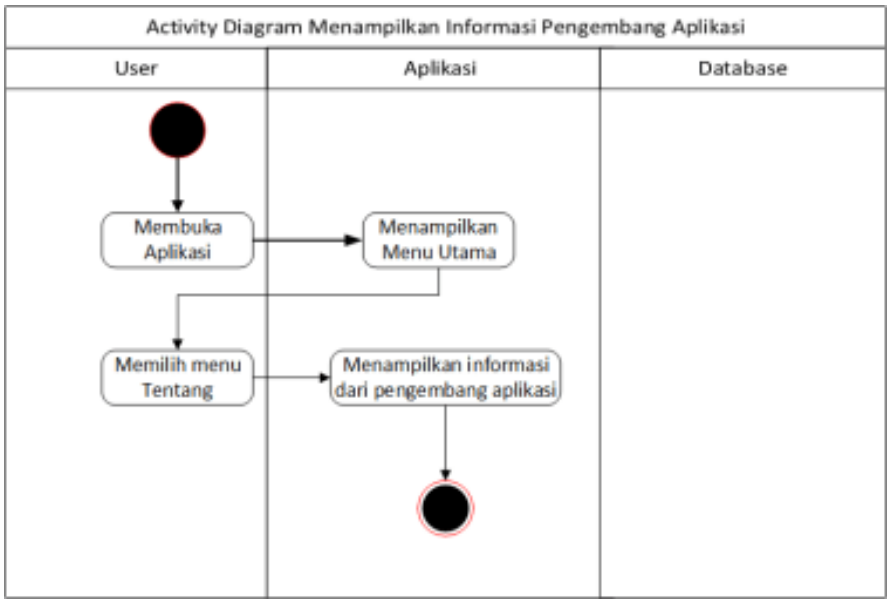

Gambar 6. Activity Diagram Menampilkan Informasi Pengembang Aplikasi

b. Batasan Perancangan Perangkat Lunak

Adapun Batasan dalam perancangan aplikasi augmented reality book simulasi perkembangbiakan hewan yaitu

1) Buku yang akan dibuat menjadi buku Augmented Reality Perkembangbiakan Hewan bersumber dari buku "Ilmu Pengetahuan Alam 6 Kelas 6 SD" oleh Dwi Suhartanti, Isnani Aziz Z dan Yulinda yang sudah sesuai dengan Kurikulum.

2) Aplikasi memiliki fasilitas play animasi, pausel resume, rotasi, zoom- in, zoom- out untuk memudahkan pengguna dalam berinteraksi dengan objek 3D.

3) Materi Pokok Perkembangbiakan Hewan yang akan diimplementasikan ke dalam aplikasi Augmented Reality Book adalah materi perkembangbiakan hewan yaitu perkembangbiakan hewan bertelur, melahirkan, bertelurmelahirkan, bertunas dan membelah diri. 
-ISSN: 2685-7006 | p-ISSN: 2252-9063

Kumpulan Artikel Mahasiswa Pendidikan Teknik Informatika

(KARMAPATI)

Volume 10, Nomor 1,Tahun 2021

\section{KARMAPATI}

c. Rancangan Antarmuka Perangkat Lunak

Terdapat 7 rancangan tampilan antar muka pada aplikasi augmented reality book simulasi perkembangbiakan hewan yaitu:

1) Rancangan Antarmuka Tampilan Splash Screen

Tampilan splash screen atau tampilan awal sebelum masuk ke menu utama.

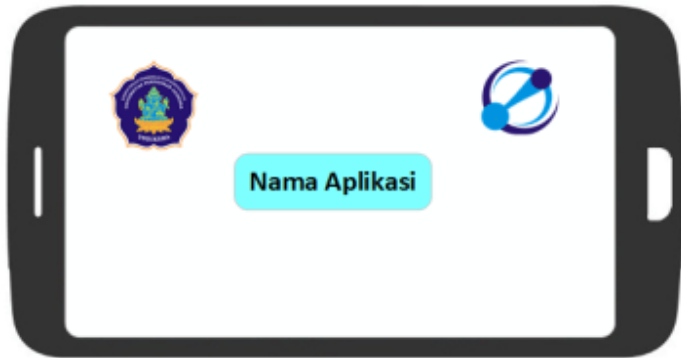

Gambar 7. Rancangan Antarmuka Tampilan Splash Screen

2) Rancangan Antarmuka Tampilan Menu Utama

Terdapat 4 jenis menu pada menu utama yaitu menu Panduan, menu Unduh Marker, menu AR Camera, dan menu Tentang. Selain itu juga terdapat 1 tombol yang berfungsi keluar dari aplikasi.

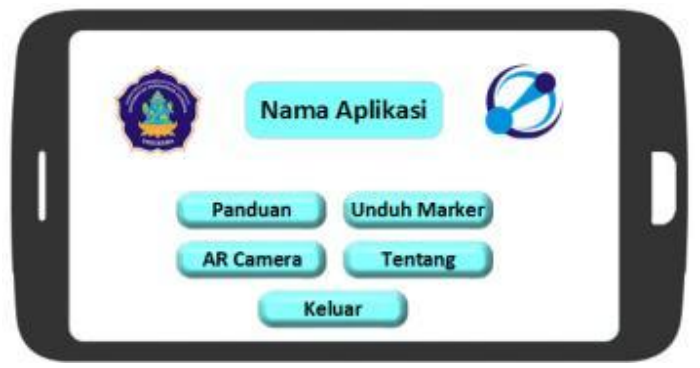

Gambar 8. Rancangan Antarmuka Tampilan Menu Utama
3) Rancangan Antarmuka Tampilan Menu Panduan

Pada menu Panduan akan menampilkan petunjuk penggunaan aplikasi.

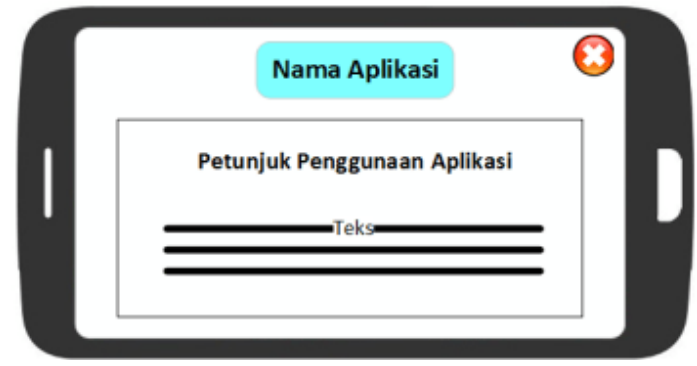

Gambar 9. Rancangan Antarmuka Tampilan Menu Panduan

4) Rancangan Antarmuka Tampilan Menu Materi

Menu Materi akan menampilkan halaman unduh Buku $A R$. Terdapat juga tombol Download untuk mengunduh Buku $A R$ dan Tombol Keluar untuk keluar dari menu Materi

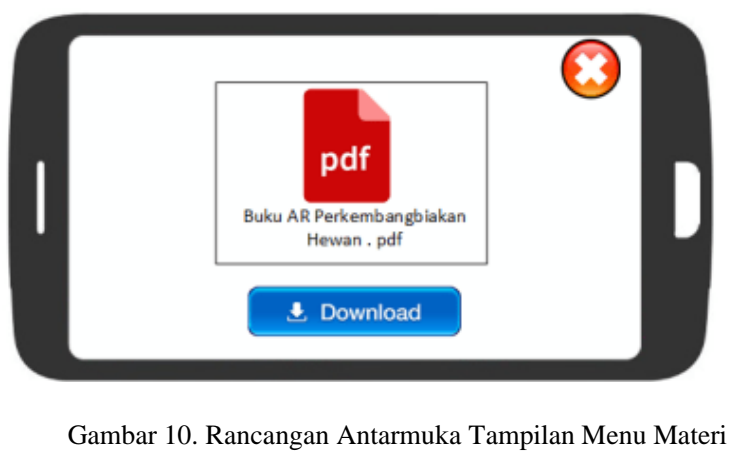

5) Rancangan Antarmuka Tampilan Menu Mulai

Menu Mulai akan menampilkan Camera $A R$ yang berfungsi melakukan prose Scan penanda/ Marker 


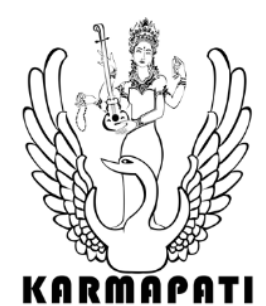

e-ISSN: 2685-7006 | p-ISSN: $2252-9063$

Kumpulan Artikel Mahasiswa Pendidikan Teknik Informatika

(KARMAPATI)

Volume 10, Nomor 1,Tahun 2021

KARMAPดTI

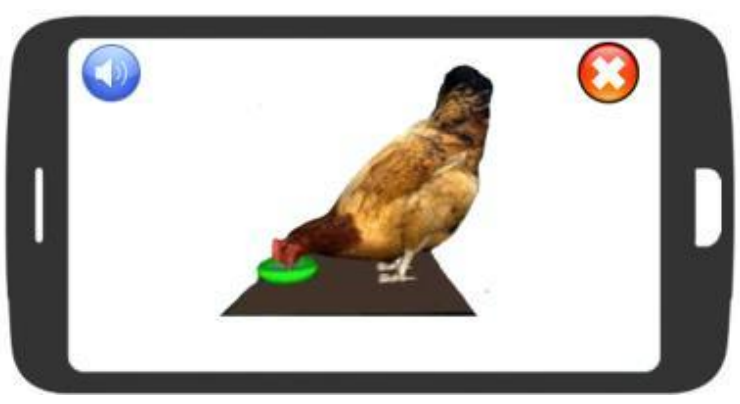

Gambar 10. Rancangan Antarmuka Tampilan Menu Mulai

6) Rancangan Antarmuka Tampilan Menu Tentang

Menu Tentang akan menampilkan informasi dari pengembang aplikasi.

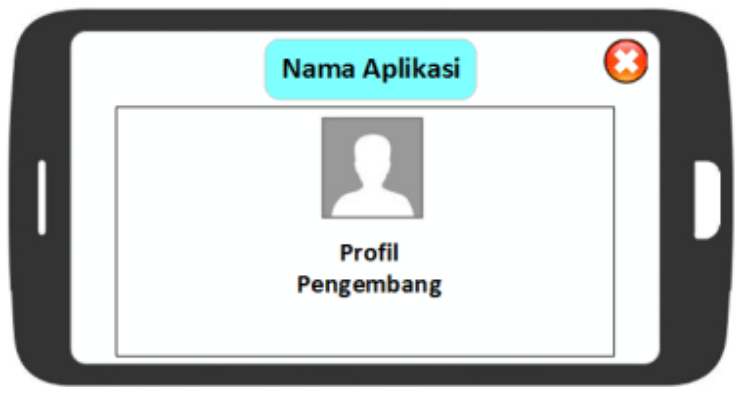

Gambar 11. Rancangan Antarmuka Tampilan Menu Tentang

\section{d. Rancangan Arsitektur Perangkat Lunak}

Perancangan arsitektur perangkat lunak menggambarkan bagian-bagian modul, struktur ketergantungan antar modul, dan hubungan antar modul dari perangkat lunak yang dibangun. Perancangan arsitektur perangkat lunak aplikasi Augmented Reality Book Perkembangbiakan Hewan digambarkan pada structure chart berikut ini.

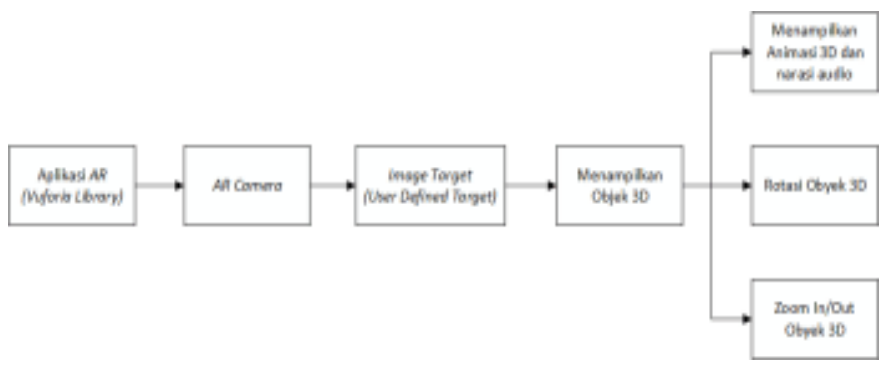

Gambar 12. Structure Chart Aplikasi Augmented Reality Perkembangbiakan Hewan

3. Pengembangan

Pembuatan aplikasi AR berbasis Android ini melewati beberapa tahapan. Tahapan pertama yakni mempelajari Buku IPA kelas VI. Tahap berikutnya yakni menyusun skenario dari materi perkembangbiakan hewan. Dari skenario yang dibuat selanjutnya dapat dijadikan dasar dalam menuliskan objek-objek 3D yang perlu dibuat. Daftar objek 3D yang perlu dibuat kemudian dijadikan dasar saat proses produksi pembuatan objek 3D berlangsung. Software yang digunakan untuk merancang objek 3D dan animasi objek 3D adalah Blender. Tahapan selanjutnya objek 3D yang dibuat kemudian ditambahkan sebagai asset pada Unity. Selain objek 3D, juga ditambahkan asset lain berupa desain 2D dan data audio apabila diperlukan. Project Unity yang telah dilengkapi dengan asset yang diperlukan selanjutnya di integrasikan dengan Vuforia. Hal ini perlu dilakukan karena Vuforia berfungsi sebagai library marker. Proses selanjutnya yaitu penulisan kode pemrograman dengan menggunakan bahasa C\# dan Javascript. Bahasa C\# digunakan untuk menambahkan fungsi- fungsi yang diperlukan pada aplikasi, sedangkan Javascript lebih pada ke tampilan aplikasi dan perpindahan scene pada Unity.

\section{Implementasi (Implementation)}

\section{a. Implementasi Materi Perkembangbiakan Hewan}

Implementasi modul aplikasi augmented reality simulasi perkembangbiakan hewan sebagai berikut:

1) Cover modul aplikasi augmented reality simulasi perkembangbiakan hewan

Terdapat logo Universitas Pendidikan Ganesha serta nama modul yaitu "Perkembangbiakan Hewan". 


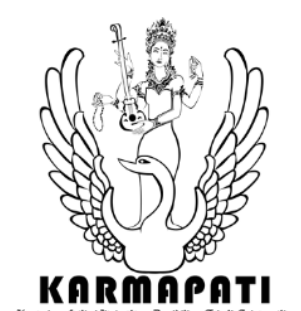

e-ISSN: 2685-7006 | p-ISSN: $2252-9063$

Kumpulan Artikel Mahasiswa Pendidikan Teknik Informatika

(KARMAPATI)

Volume 10, Nomor 1,Tahun 2021

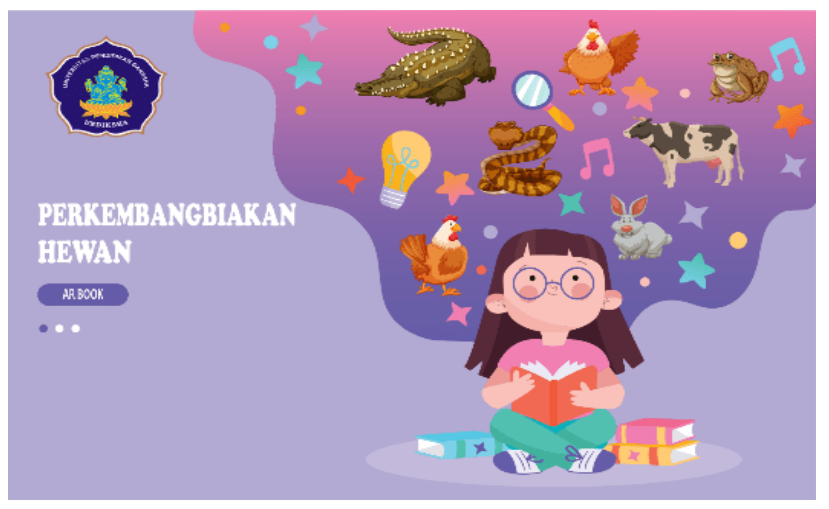

Gambar 13. Implementasi Cover Modul Aplikasi

2) Implementasi isi modul aplikasi augmented reality simulasi perkembangbiakan hewan

Terdapat materi perkembangbiakan hewan dan juga Penanda/ Marker berupa gambar.

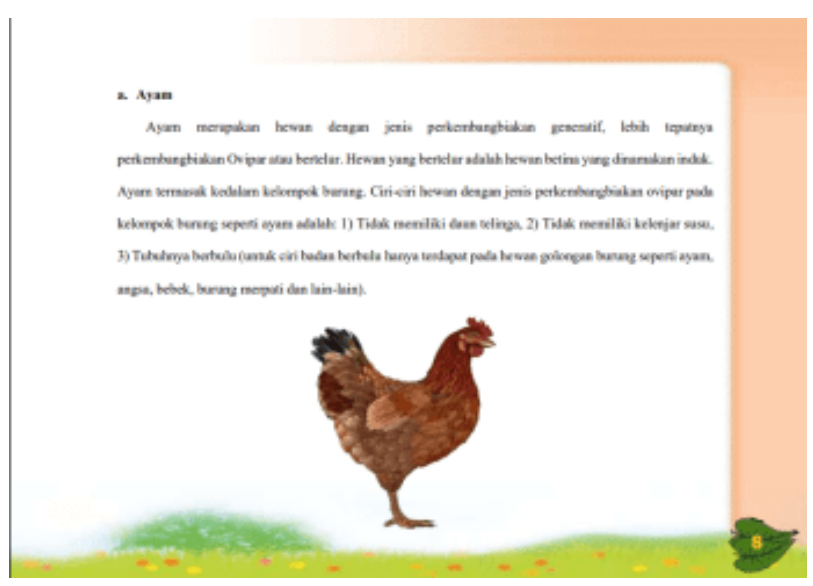

Gambar 14. Implementasi Isi Modul Aplikasi

b. Implementasi Penanda/ Marker

Sesuai dengan perancangan model fungsional yang telah dibuat, diperlukan penanda/ marker yang diletakkan pada modul buku $A R$ untuk dilacak/ dipindai oleh kamera smart phone yang sudah terinstal aplikasi augmented realty. Aplikasi Perkembangbiakan Hewan Berbasis Augmented Reality menggunakan device data yaitu gambar-gambar penanda yang sudah siap digunakan di unggah ke situs resmi Vuforia, kemudian gambar penanda tersebut diproses sehingga menjadi file library Perkembangbiakan.unitypackage untuk di unduh. Aplikasi ini menggunakan 15 gambar yang di implementasikan sebagai penanda/ marker.

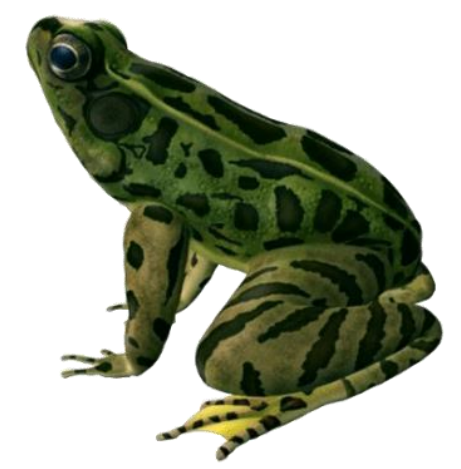

Gambar 15. Implementasi Penanda/ Marker

\section{c. Implementasi Object 3D}

Tahapan pembuatan objek serta animasi 3 dimensi materi perkembangbiakan hewan dibuat dengan menggunakan aplikasi Blender.

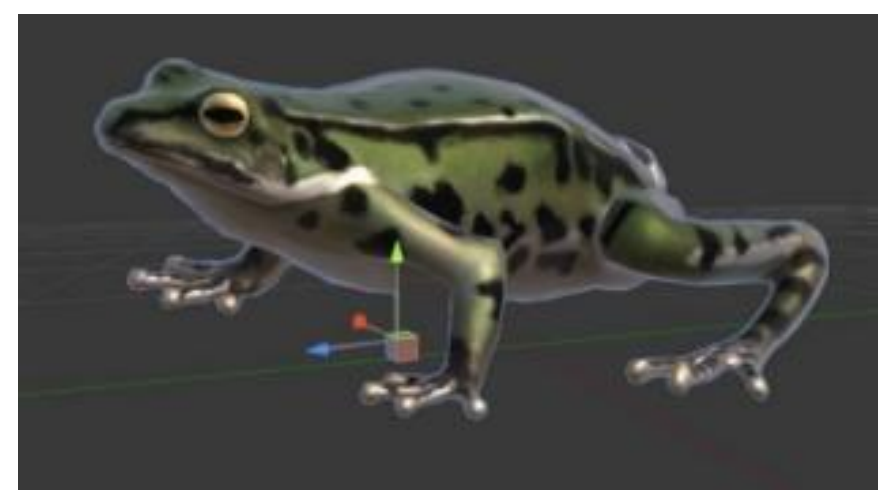

Gambar 16. Implementasi Objek 3D Perkembangbiakan Hewan

d. Implementasi Antarmuka Perangkat Lunak 


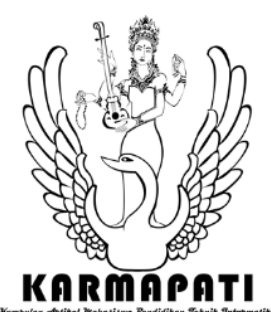

e-ISSN: 2685-7006 | p-ISSN: $2252-9063$

Kumpulan Artikel Mahasiswa Pendidikan Teknik Informatika

(KARMAPATI)

Volume 10, Nomor 1,Tahun 2021

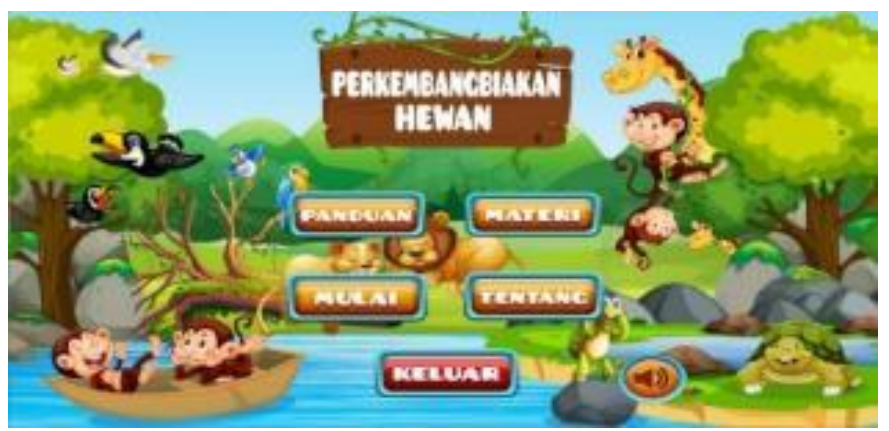

(a)

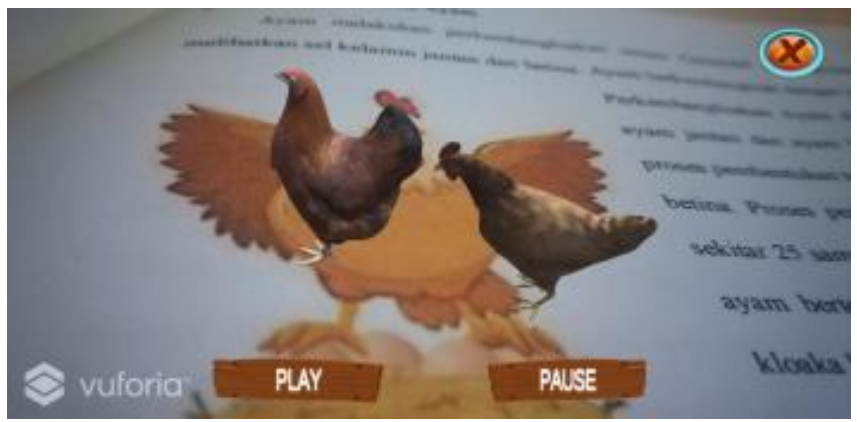

(b)

Gambar 17. Implementasi Antarmuka Perangkat Lunak, (a) Implementasi Tampilan Menu Utama, (b) Tampilan Scan Marker AR

\section{Evaluasi (Evaluation)}

Setelah tahap implementasi perangkat luak selesai dilakukan, maka selanjutnya adalah tahap evaluasi. Adapun hasil pengujian nya sebagai berikut:

\section{a) Hasil Uji White Box}

Pada pengujian white box digunakan untuk mengetahui cara kerja suatu perangkat lunak secara internal. Hasil pengujian white box diperoleh persentase keberhasilan $100 \%$.

\section{b) Hasil Uji Black Box}

Pada pengujian kasus uji 1 bertujuan untuk menguji kebenaran proses dari aplikasi Augmented Reality Perkembangbiakan Hewan. Hasil pengujian diperoleh persentase keberhasilan 100\%, kemudian pada kasus uji 2 dilakukan untuk mengetahui apakah aplikasi Augmented Reality Perkembangbiakan Hewan sudah berjalan dengan baik dan dapat digunakan pada device yang berbeda. Dengan pengujian menggunakan 5 hardware yang berbeda diperoleh persentase keberhasilan $100 \%$.

\section{c) Hasil Uji Ahli Isi}

Pada uji ahli isi dilakukan oleh 2 orang ahli yaitu guru kelas VI Sd Negeri 4 Suwug dan satu orang dosen jurusan Pendidikan Sekolah Dasar Undiksha. Dari pelaksanaan uji ahli isi diperoleh hasil perhitungan 1.00 yang artinya tingkat pencapaian isi dari media pembelajaran berbasis augmented reality book perkembangbiakan hewan adalah sangat tinggi.

\section{d) Hasil Uji Ahli Media}

Pada uji ahli media dilakukan oleh 2 orang ahli yaitu dua orang staf dosen dari program studi Pendidikan Pendidikan Teknik Informatika Undiksha. Dari pelaksanaan uji ahli media diperoleh hasil perhitungan 1.00 yang artinya tingkat pencapaian dari media pembelajaran berbasis augmented reality book perkembangbiakan hewan adalah sangat tinggi.

\section{e) Hasil Uji Lapangan}

Syarat dilakukannya uji lapangan yaitu media pembelajaran berbasis augmented reality book perkembangbiakan hewan sudah dinyatakan layak uji coba lapangan tanpa revisi oleh ahli isi dan ahli media. Uji lapangan melibatkan 10 orang siswa SD Negeri 4 Suwug. Dari analisis uji lapangan dengan 10 subyek (butir) penilaian diperoleh hasil persentase sebesar $93.4 \%$.

\section{Kesimpulan}

Kesimpulan yang diperoleh dari hasil dan pembahasan penelitian pengembangan media pembelajaran berbasis augmented reality book simulasi perkembangbiakan hewan, antara lain adalah sebagai berikut:

Rancangan media pembelajaran berbasis augmented reality book simulasi perkembangbiakan hewan menggunakan model ADDIE (Analysis- Design- Develop-Implement- Evaluate). Salah satu fungsinya $A D D I E$ yaitu menjadi pedoman dalam membangun perangkat dan infrastruktur program pelatihan 


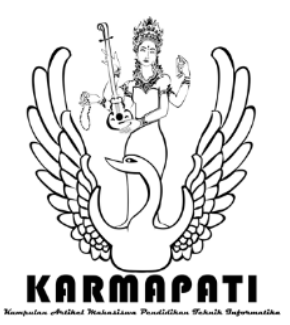

yang efektif, dinamis dan mendukung kinerja pelatihan itu sendiri. Model ini menggunakan 5 tahap pengembangan yakni: Analysis (analisa), Design (desain/ perancangan), Development (pengembangan), Implementation (implementasi) dan Evaluation (evaluasi).

Sudah berhasil mengembangkan media pembelajaran berbasis augmented reality book simulasi perkembangbiakan hewan sesuai dengan alur pengembangan aplikasi yaitu model pengembangan $A D D I E$ yang dimulai dari tahap analisis pembelajaran/ kurikulum dan analisis kebutuhan merupakan kegiatan menentukan pembelajaran yang menjadi objek pengembangan. Pada tahap desain dilakukan perancangan aplikasi dan perancangan antarmuka di Ms. Word dan desain layout buku menggunkan aplikasi Adobe Photashop CC 2015, Pembuatan objek 3D menggunakan aplikasi Blender 2.78 dan objek 3D dengan marker penanda yang sebelumnya telah didaftarkan di situs Vuforia digabungkan menggunakan aplikasi Unity. Pada tahap suara narasi/ dubbing aplikasi yang digunakan adalah aplikasi Audacity 2.1.0, Selanjutnya sebagai produk akhir dari aplikasi ini adalah sebuah buku dan aplikasi. Penulis menggunakan aplikasi adobe photoshop CC 2015 untuk mendesain tampilan buku, dan aplikasi Unity sebagai build apk.

Berdasarkan proses pengujian media pembelajaran berbasis augmented reality book simulasi perkembangbiakan hewan dengan pengujian white box dan Black box dapat diperoleh persentase keberhasilan 100\%. Berdasarkan penilaian dari ahli isi dan ahli media dapat di analisa rata-rata keseluruhan penilaian yaitu 1.00 yang berarti media pembelajaran berbasis augmented reality book simulasi perkembangbiakan hewan "Valid" dan layak digunakan dalam pembelajaran. Selanjutnya untuk pengujian pengguna didapat persentase respons siswa sebesar $93.4 \%$ yang berarti media pembelajaran berbasis augmented reality book simulasi perkembangbiakan hewan berada dalam kategori sangat baik

\section{REFRENSI}

[1]. Arsyad, Azhar. (2003). Media Pembelajaran, Jakarta: Raja Grafindo Persada.

[2]. Sadiman, Arief S. (2007). "Media Pendidikan, Pengertian, pengembangan dan Pemanfaatanya”. Jakarta: Raja Grafindo Persada

[3]. Burhanudin, Ahmad. (2017). "Pengembangan Media Pembelajaran Augmented Reality pada Mata Pelajaran Dasar Elektronika di SMK Hamong Putera 2 Pakem”. Journal Universitas Negeri Yogyakarta

[4]. Susanto, Ahmad. (2013). "Teori-teori Pembelajaran di Sekolah Dasar". Jakarta: Kencana.

[5]. Suhartanti. Dwi., Isnani A.Z., \& Yulinda. (2008). "Buku Ilmu Pengetahuan Alam 6 Kelas 6 SD”. Jakarta: Pusat Perbukuan Departemen Pendidikan Nasional.
e-ISSN: 2685-7006 | p-ISSN: 2252-9063

Kumpulan Artikel Mahasiswa Pendidikan Teknik Informatika

(KARMAPATI)

Volume 10, Nomor 1,Tahun 2021
[6]. Laman, C. (2005). "Applying UML and Paterns (3rd Edition)”. New York: Pearson Education International.

[7]. Lisiswanti, R., Saputra, O., Windarti, I., \& Anatomi. (2015). Peranan Media dalam Pembelajaran. 102-105.

[8]. Sugiato. (2014). "Implementasi Augmented Reality pada Brosur Rental Mobil CV Asmoro Jati menggunakan Metode Marker". Semarang: Universitas DIAN NUSWANTORO.

[9]. Lyu, Michael R. (2012). "Digital Interactive Game Interface Table Apps for Ipad". Jurnal Penelitian. The Chinese University of Hongkong.

[10]. Widnyana, I. M. (2015). "Pengembangan Aplikasi Augmented Reality Book Pengenalan Kamera Foto sebagai Penunjang Pembelajaran Fotografi Study Kasus Kelas XII- Multimedia SMK Negeri 1 Mas Ubud”. KARMAPATI ISSN 2252- 9063.

[11]. Abdullah, Fatchirrohman. (2012). "Pembuatan Media Publikasi Komodo Berbasis Multimedia Menggunakan Game Edukasi dan Teknologi Augmented Reality". Skripsi. AMIKOM.

[12]. Nugroho, A. (2017). "Aplikasi Mobile Augmented Reality Berbasis Vuforia dan Unity pada Pengenalan Objek 3D dengan Studi Kasus Gedung M Universitas Semarang”. Jurnal Trasformatika. Volume 14, Nomor 2.

[13]. Team, B. (2017). blender.org. Retrieved Februari 23, 2019, from blender: https://www.blender.org/.

[14]. Safaat, Nazruddin. (2015). "Pemrograman Aplikasi Mobile Smart phone dan Tablet PC Berbasis Android”. Bandung: Penerbit Informatika. 